trial comparing the efficacy of subcutaneous low dose cytarabine alone or in combination with isotretinoin versus supportive treatment alone. The therapeutic potential of interferons, haemopoietic growth factors, and other biological response modifiers is currently being evaluated. Preliminary results suggest that these may provide a novel strategy for treating myelodysplastic syndromes.

D M LAYTON Sir John Dacie fellow

G J MUFTI

Senior lecturer

Department of Haematology,

King's College School of Medicine

and Dentistry,

London SE5 8RX

1 Parkes-Weber F. A case of leukanaemia. Transactions of the Pathological Society of London 1904;55:288-96.

2 Bennett JM, Catovsky D, Daniel M-T, et al. The French-American-British cooperative group Proposals for the classification of the myelodysplastic syndromes. Br $\mathcal{F}$ Haematol 1982;51 $189-99$.

3 Wegelius R. Preleukaemic states in children. Scand J Haematol [Suppl] 1986;36:133-9.

4 Michels SD, McKenna RW, Arthur DC, Brunning RD. Therapy related acute myeloid leukemia and myelodysplastic syndrome: a clinical and morphological study of 65 cases. Blood 1986;65:1364-72.

5 Mufti GJ, Oscier DG, Hamblin TJ, Nightingale A, Darlow S. Serous effusions in monocytic leukaemias. Br $\mathcal{F}$ Haematol 1984:58:547-52.

6 Duguid JKM, Mackie MJ, McVerry BA. Skin infiltration associated with chronic myelomonocytic leukaemia. Br $\mathcal{H}$ Haematol 1983;53:257-64.

monocytic leukaemia. Br Foematol $1983 ; 53: 257-64$.
Boogaerts MA, Nelissen V, Roelant C, Goossens W. Blood neutrophil function in primary myelodysplastic syndromes. Br $\mathcal{I}$ Haematol 1983;55:217-27.

8 Lintula R, Rasi V, Ikkala E, Bergstrom GH, Vuopio P. Platelet function in preleukaemia. Scand $\mathcal{J}$ Haematol 1981;96:65-71.

9 Yunis JJ, Rydell RE, Oken MM, Arneson MA, Mayer MG, Lobell M. Refined chromosomal analysis as an independent prognostic indicator in de novo myelodysplastic syndromes. Bloo 1986;67:1721-30.

10 Van den Berghe H. The Sq- syndrome. Scand J Haematol [Suppl] 1986;36:78-81

11 Copplestone JA, Mufti GJ, Hamblin TJ, Oscier DG. Immunological abnormalities in myelodysplastic syndromes. II. Coexistent lymphoid or plasma cell neoplasms: a report of 20 cases unrelated to chemotherapy. Br f Haematol 1986;63:149-59.

12 Bynoe AG, Scott CS, Ford P, Roberts BE. Decreased T-helper cells in the myelodysplastic syndromes. BrF Haematol 1983;54:97-102.

13 Kerndrup G, Mayer K, Ellegard J, Hokland P. Natural killer (NK) activity and antibody dependent cellular cytotoxicity (ADCC) in primary preleukemia syndrome. Leuk Res 1984;8: $239-47$.

14 Mufti GJ, Galton DAG. Myelodysplastic syndromes: natural history and features of prognostic importance. Clin Haematol 1986;15:953-71.

15 Mertelsmann R, Thaler HT, To L, et al. Morphological classification, response to therapy and survival in 263 adult patients with acute non-lymphocytic leukemia. Blood 1980;56:773-81.

16 Armitage JO, Dick FR, Needleman SW, Burns CP. Effect of chemotherapy for the dysmyelopoietic syndrome. Cancer Treat Rep 1981;65:601-5.

17 Appelbaum FR, Storb R, Ramberg RE, et al, Allogeneic marrow transplantation in the treatment of preleukemia. Ann Intern Med 1984;100:689-93.

18 Breitman TE, Selonick SE, Collins SJ. Induction of differentiation of the human promyelocytic leukemia cell line (HL60) by retinoic acid. Proc Natl Acad Sci USA 1980;77:2936-40.

19 Griffin J, Munroe D, Major P, Kufe D. Induction of differentiation of human myeloid leukemia cells by inhibitors of DNA synthesis. Exp Hematol 1982;10:774-81.

20 Mufti GJ, Oscier DG, Hamblin TJ. Low dose cytarabine (Ara-C) in the treatment of myelodysplastic syndromes (MDS) and acute myeloid leukaemia (AML). Brf Haematol 1985;61:571.

\section{The psychiatry of HIV infection}

All the various forms of infection with the human immunodeficiency virus (HIV) can have an important psychological impact..$^{1-3}$ Indeed, psychological problems are also seen in those uninfected but anxious that they might be-the "worried well." The recent international conference on the acquired immune deficiency syndrome (AIDS) discussed all the psychological problems that may be associated with HIV infection (third international AIDS conference, Washington DC, June 1987).

HIV may cause a presenile dementia called the AIDS dementia complex. ${ }^{4}$ The typical features are motor slowing, poor concentration, and memory loss. Most patients deteriorate steadily, but in about a fifth the disease runs an indolent course. At its most advanced the dementia may be severe, with mutism, incontinence, paraplegia, and myoclonus." At the conference $\mathrm{Dr} R$ Vazeuz and her colleagues described how they localised HIV proteins in the brains of patients with AIDS to macrophages normally resident in the brain and not to neurones or astrocytes.

A battery of neuropsychological tests on over 180 patients with AIDS followed up for three years showed that half developed important cognitive impairment (S Tross et al, AIDS conference, Atlanta, Georgia, 1985). These tests are, however, time consuming to use, and a new development is a brief clinically orientated battery that correlates well with a more exhaustive one (J J Sidtis $e t a l$ ). It has been used to confirm that the more severe the somatic infection with HIV the worse the cognitive dysfunction.

Patients infected with HIV selected from an American cohort of 5000 homosexuals showed widespread minor abnormalities in cognitive function, but only $2 \%$ had early AIDS dementia complex (J C McArthur et al). A smaller study (I Grant et al) found that as many as $44 \%$ of otherwise asymptomatic subjects had appreciable cognitive impairment (compared with $9 \%$ of healthy uninfected gay men, $54 \%$ of patients with AIDS related complex, and $87 \%$ of patients with AIDS). In another study half the patients with î polyglandular lymphodenopathy had evidence of cognitive or impairment and peripheral neurological disorders ( $R S$ Janssen $e t a l$ ).

The commonest reasons for referring patients with AIDS N to a liaison psychiatry service were depression $(16 \%)$, suicidal ideation $(16 \%)$, and treatment refusal $(7 \%)$. Other reasons for referral were agitation, anxiety, and inability to cope. A o quarter were diagnosed as having adjustment disordersprolonged maladaptive reactions causing appreciable social

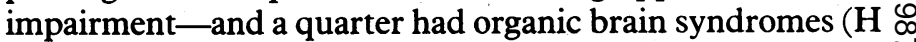
W Weisman et $a l$ ). Adjustment disorders have been found in : $60 \%$ of those with AIDS related complex, $41 \%$ of those with AIDS, and $23 \%$ of asymptomatic but infected patients. Major depression is less common (occurring in $15 \%$ of those with AIDS related complex, $13 \%$ of those with AIDS, and $5 \%$ of those who are asymptomatic) and generalised anxiety disorder rare (occurring in 15\% of those with AIDS related complex, none of those with AIDS, and $5 \%$ of those who are asymptomatic) (S Tross et $a l$ ). Severe depression may have an organic component, and treatment with antidepressant drugs may thus not be effective; the drugs, particularly those with anticholinergic effects, may precipitate confusional states. ${ }^{5-7}$

At the conference Dr D Miller showed that many patients 0 - the worried well-had presented because of the publicity surrounding AIDS. They are similar to patients with syphilis $ᄋ$ phobia and are obsessional and rigid and have never had $N$ sexually transmitted diseases. They misinterpret various $\rightarrow$ somatic complaints, have many tests without relief of anxiety, and demand frequent reassurance from the doctor. $N$ Their anxiety is difficult to allay, and they may develop $\underset{\mathrm{C}}{\mathrm{N}}$ persistent and refractory depressions.

Health workers may need to confront their own prejudices towards the high risk groups in order to offer the highest $\mathbb{\Phi}$ standard of care.$^{8-10}$ Doctors' responses to four nearly identical $\stackrel{?}{+}$ case vignettes depended on whether the patient described $\frac{0}{\circ}$ had AIDS or leukaemia and was either homosexual or $\overrightarrow{\mathbb{D}}$ heterosexual (J S St Lawrence et $a$ ) : doctors believed that homosexual patients with AIDS deserved their diagnoses and were less deserving of the doctor's sympathy.

We are only just learning about the consequences of HIV infection on human behaviour, and the psychiatric

\title{
管
}


consequences are protean. What is needed now is more understanding of those at risk of AIDS and compassion for their struggle to come to terms with premature death.

\section{STEPHEN W BURTON}

Honorary Senior Registrar in Psychiatry,

AIDS Research Unit,

St Stephen's Hospital,

London SW10 9TH

1 Faulstich M. Psychiatric aspects of AIDS. Am f Psychiatry 1987;144:551-6.

2 Batchelor WF A public health and psychological emergency. Am Psychol 1984:39:1279-84.

3 Hays LR, Lyles MR. Psychological themes in patients with acquired immune deficiency syndrome. Am f Psychiatry 1986;143:551.

syndrome. Am f Pychiatry 1986;143:551. 1986;19:517-24.

Loewenstein RJ, Sharfstein SS. Neuropsychiatric aspects of acquired immune deficiency syndrome. Int I Psychiatry Med 1984;13:255-60.

6 Perry S, Jacobsen P. Neuropsychiatric manifestations of AIDS-spectrum disorders. Hosp Community Psychiatry 1986;37:135-42.

Price WA, Forejt J. Neuropsychiatric aspects of AIDS: a case report. Gen Hospital Psychiatry 1986;8:7-10.

8 Dilley JW, Ochitill HN, Perl M, et al. Findings in consultation with patients with the acquired mmune deficiency syndrome. Am f Psychiatry 1985;142:82-6.

9 Morton AD, McManus IC. Attitudes to and knowledge about the acquired immune deficiency syndrome: lack of a correlation. BrMed f 1986;293:1212.

10 Douglas CJ. Kalnan CM, Kalnan TP. Homophobia among physicians and nurses: an empirical study. Hosp Community Psychiatry 1985;36:1309-11.

The references mentioned only in the text are to papers presented at the third international AIDS conference.

\section{Medicine and the fate of tropical forests}

Reserpine, tubocurarine, and vincristine or vinblastine come to the doctor originally not from a laboratory but from the jungle. The pharmaceutical industry may have refined and adapted, but the inventions were made respectively by an Indian shrub (Rauwolfia serpentina), a Brazilian vine (Chondrodendron tomentosum), and a Madagascan herb (Catharanthus (Vinca) roseus). ${ }^{1}$

Many other drugs and drug families also come from the plants of the world's tropical forests-for example, the quinine related antimalarials from the Peruvian tree Cinchona ledgeriana; the amoebicidal emetine from a Brazilian shrub Cephaelis ipecacuanha; and the cocaine related local anaesthetics from the Andean shrub Erythroxylum coca. Almost imperceptibly medicines from tropical plants have come to dominate much of the pharmaceutical market, where already one product in four is derived from wild plants. $^{2}$ As well as being therapeutically useful these medicines are worth collectively at least $£ 35$ billion annually. ${ }^{3}$ Thus we must consider the nature and future of the forests from which such useful chemicals have originated and from which many more may be expected to emerge.

The identification, analysis, and evaluation of forest medicines represent a continuing and possibly accelerating process. Many data have been collected on how forest dwelling people use tropical plants-for example, in Amazonia by Schultes, ${ }^{4}$ in the West Indies and West Africa by Ayensu, ${ }^{56}$ and in East and South East Asia by Perry. This approach (known as ethnobotany) uses indigenous experience based on generations of trial and error to draw attention to those plants most likely to yield useful compounds. ${ }^{8}$ Ethnobotanical surveys in tropical rain forests may be especially productive. One conducted recently in south eastern Peru compiled basic data on the human use of 175 species of medicinal plants at one community ( $M$ Alexiades and D Lacaze, unpublished observations). Several have been investigated in the laboratory: a local anaesthetic was found in a novel piperaceous shrub and a sedative in a bignoniaceous climber. Meanwhile, the latex of a fig from the same area, Ficus glabrata, has been evaluated clinically and shown to be a potent and well tolerated antihelminthic agent. ${ }^{9}$

Yet only about one species in 100 has yet been screened for potential value to medicine or any other discipline. Much remains to be done, and since four fifths of all plant species live only within tropical forests it will be done only if these forests can be conserved.

The extreme chemical richness of tropical forests matches their taxonomic diversity: a greater proportion of species contain alkaloids (the class of compounds to which quinine, vinblastine, and reserpine belong) and other "secondary compounds" than in any other kind of vegetation-and the average tissue concentration is also much higher. ${ }^{2}$ These secondary compounds include a wide range of chemicals derived from plant metabolism-for instance, cardiac and cyanogenic glycosides, terpenoids, glucosinolates, saponins, phytohaemagglutinins, proteinase inhibitors, flavonoids, and tannins. ${ }^{1011}$ Most such chemicals seem to be there to defend the plant against attack by animals (especially insects) and micro-organisms. Their sites of action are various, but their net effect is to discourage predation and premature decay; for example, they may make leaves inedible to grazers or preserve fruits until they can be eaten by dispersing animals.

There are good evolutionary reasons why tropical moist forests are so rich in chemicals. Firstly, since there are so many species each is specialised-and therefore efficient in its own way-at retrieving nutrients from its environment in competition with others. Thus once a plant has succeeded in accumulating enough scarce raw materials to be able to grow a leaf it must be able to protect that leaf-it is just too valuable to lose. Although filling a leaf with toxic chemicals costs the plant further energy, the hostile rain forest environment makes this worth while. Secondly, the absence of winter in the rain forest means that the threat of predation is continuous. In temperate lands plants have an annual holiday from predation and can do most of their growing in spring before their enemies' numbers build up. In a rain forest, however, the threat of predation is not only continuous but also intense-so plants have been under great pressure to evolve defensive chemicals. Since these will have been selected specifically to affect animal systems or to inhibit fungal and bacterial growth it is logical that potential pharmaceuticals should be abundant among them.

With so much of benefit to medicine still to be found in the tropical forests of the world it is distressing that these forests are being destroyed at a high and accelerating ratepresently at least 100 acres a minute worldwide. Many species are becoming extinct each year. The erosion of mankind's culturally acquired knowledge of rain forest medicine is even more critical: almost all ethnolinguistic groups indigenous to such forests are rapidly "forgetting" this skill under the impact of dominant cultures and new economic patterns. The fate of tropical forests is linked to the future of medicine-both as a source of many new drugs and as a gene bank for "growing pharmacies" in tropical villages (where effective herbal remedies can be provided at low cost to poor people). The time has come when to be a 